\title{
Structural Investigations of Substituted Silacyclopropylidenoids through Computational
}

\section{Techniques}

\author{
$\underline{\text { Cem Burak Yildiz }}^{1,2^{*}}$ and Akın Azizoglu ${ }^{1}$ \\ ${ }^{1}$ Laboratory of Computational Chemistry, Department of Chemistry, University of Balikesir, TR-10145, \\ Balikesir, Turkey \\ ${ }^{2}$ Department of Chemistry, University of Aksaray, TR-68100, Aksaray, Turkey \\ cbyildiz@gmail.com
}

\begin{abstract}
The "ab initio" (MP2) level of theory using 6-311+G(d,p) basis set has been carried out to explore the isomeric structures, energies, and properties of substitued $\left(-\mathrm{H},-\mathrm{CH}_{3},-\mathrm{SiH}_{3},-\mathrm{OH}\right)$ $\mathrm{LiBr}$-silacyclopropylidenoids. The resulting isomeric structures of $\mathrm{LiBr}$-silacyclopropylidenes reveal three stationary structures: silylenoidal $(\mathbf{S})$, inverted $(\mathbf{I})$, and tetrahedral $(\mathbf{T})$. The theoretical calculations indicate that all substituted LiBr-silacyclopropylidenoids have silylenoidal (S), inverted (I), and tetrahedral (T) forms except $-\mathrm{OH}$ substituted silylenoid. Interestingly we have obtained no tetrahedral structure as a minimum for the $-\mathrm{OH}$ substituted structure. The silylenoidal forms energetically more stable than the inverted (I) and tetrahedral (T) forms, whereas stability of the tetrahedral (T) forms for the title structures lower than the inverted (I) and silylenoidal (S) forms.
\end{abstract}

Keywords: ab initio, silacyclopropylidenoids

\section{Introduction}

Silylenoids, $\mathrm{R}_{2} \operatorname{SiMX}(\mathrm{X}=$ halogen, $\mathrm{M}=$ alkali metal), are important intermediates in silicon hybrid and organosilicon chemistry $[1,2]$. As a kind of very reactive species, the preparation of silylenoids is very difficult. In recent decades, the synthesis and chemistry of silylenoids have attracted attention from the viewpoints of both fundamental and applied chemistry. Clark et al. [3] have carried out the first theoretical study on the simplest silylenoid $\mathrm{H}_{2} \mathrm{SiLiF}$, and then many silylenoids such as $\mathrm{H}_{2} \mathrm{SiMX}(\mathrm{M}=\mathrm{Li}, \mathrm{Na}, \mathrm{K} ; \mathrm{X}=\mathrm{F}, \mathrm{Cl}, \mathrm{Br}), \mathrm{R}_{2} \mathrm{SiLiF}$ 
( $\mathrm{R}=\mathrm{CH}_{3}, \mathrm{CH}_{2} \mathrm{CH}_{3}$ ), and $\mathrm{C}_{2} \mathrm{H}_{4} \mathrm{SiMX}$ (where $\mathrm{M}=\mathrm{Li}$ or $\mathrm{Na}$ and $\mathrm{X}=\mathrm{F}, \mathrm{Cl}, \mathrm{Br}$ ) [4-14] have been systematically investigated.

The silacyclopropylidenoid, the silicon analogue of cyclopropylidenoid, is a compound in which an electropositive metal (M) and a leaving group (X, usually halogen) are bound to the same silicon atom. Contrast to extensive experimental and computational studies on cyclopropylidenoids [15-17], only a few scientific work on silacyclopropylidenoids has been reported so far.

More recently, we have carried out a series of $a b$ initio calculations on the isomeric structures, energies, and the properties of silacyclopropylidenoids, $\mathrm{C}_{2} \mathrm{H}_{4} \mathrm{SiMX}$ (where $\mathrm{M}=\mathrm{Li}$ or $\mathrm{Na}$ and $\mathrm{X}=\mathrm{F}, \mathrm{Cl}, \mathrm{Br}$ ). The theoretical results reveal that three stationary structures for each of $\mathrm{C}_{2} \mathrm{H}_{4} \mathrm{SiMXs}$, silacyclopropylidenoid (S), tetrahedral (T), and inverted (I), were located on the potential energy surfaces (PES) at the MP2/6-31+G(d,p) and MP2/aug-cc-pVTZ levels of theory (Scheme 1). Computed energy differences between them range from 0.70 to 8.70 $\mathrm{kcal} / \mathrm{mol}$ at the MP2/6-31+G(d,p) level [14].

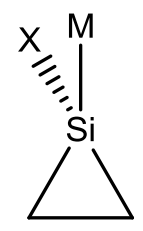

(S)

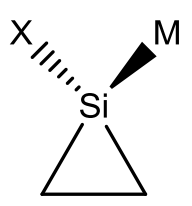

(T)

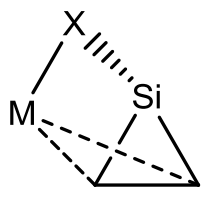

(I)

Scheme 1. The silacyclopropylidenoid (S), tetrahedral (T), and inverted (I) forms of $\mathrm{C}_{2} \mathrm{H}_{4} \mathrm{SiMX}$ (where $\mathrm{M}=\mathrm{Li}$ or $\mathrm{Na}$ and $\mathrm{X}=\mathrm{F}, \mathrm{Cl}, \mathrm{Br}$ ) complexes.

In the present paper, we wish to provide the first computational study of the geometries, electronic structures, and the stabilities of substituted silacyclopropylidenoids (Figure 1, $\mathrm{X}=-\mathrm{H},-\mathrm{CH}_{3},-\mathrm{SiH}_{3}$, and $-\mathrm{OH}$ ). The overall stabilities of silacyclopropylidenoid isomers are also compared and the main factors contributing to the stability of the isomers are simply discussed.

\section{Computational Methods}

Optimized geometries and energies for the stationary points were obtained using density functional theory at the MP2/6-311+G(d, p) level [19]. The corresponding harmonic vibrational frequency calculations were carried out in order to verify whether the stationary 
points are local minima (no imaginary frequencies) or saddle points (one imaginary frequency) with help of Gaussian03 package program [20]. The computed structures were visualized by using the GaussView3.0 program [21].

\section{Results and Discussion}

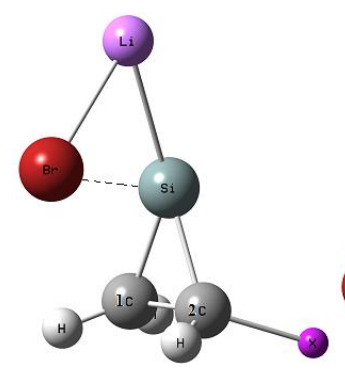

(S)

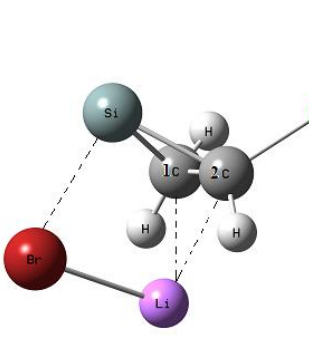

(I)

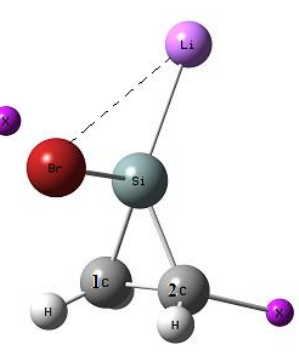

(T)

Figure 1. The general representation of silylenoidal $(\mathbf{S})$, inverted $(\mathbf{I})$, and tetrahedral $(\mathbf{T})$ form of the title structures $\left(\mathrm{X}=-\mathrm{H}, \mathrm{CH}_{3},-\mathrm{SiH}_{3},-\mathrm{OH}\right)$.

$\mathrm{C}_{3} \mathrm{H}_{4} \mathrm{LiBr}$ can be regarded as a carbenoid formed by free cyclopropylidene and $\mathrm{LiBr}$ moieties. In this study, we studied substituted $\left(\mathrm{X}=-\mathrm{H}, \mathrm{CH}_{3},-\mathrm{SiH}_{3},-\mathrm{OH}\right)$ silicon analogues of cyclopropylidenoids are shown in Figure 1. The structure of silacyclopropylidenoid $\left(\mathrm{C}_{2} \mathrm{SiH}_{4} \mathrm{LiBr}\right)$ has three equilibrium configurations [14], in which the $\mathbf{S}$ form is the lowest in energy. The theoretical calculations depict that "- $\mathrm{H}, \mathrm{CH}_{3}$, and $-\mathrm{SiH}_{3}$ " substituted silacyclopropylidenoids have three stationary structures: silylenoidal (S), inverted (I), and tetrahedral (T). However, the tetrahedral (T) geometry could not be optimized for "-OH" substituted structure. To indicate that no suitable geometry and energy results were obtained, dashes (-) were placed into Table 2. From calculated energies of the title structures, the $\mathbf{S}$ forms are more stable than the $\mathbf{I}$ and $\mathbf{T}$ forms at MP2/6-311+G(d,p) theory of levels.

It is emphasized from the NBO analysis that positively charged ion, $\mathrm{Li}+$, attach the carbonic Si atom to give minimal structures $(\mathbf{S}, \mathbf{I}$, and $\mathbf{T})$ which have low-energy. In the inverted (I) form, the $\mathrm{Li}$ atom is positioned between the $\mathrm{C} 1$ and $\mathrm{C} 2$ atoms and interacts mostly with the $\mathrm{C}$ atoms. There is a non-bonding interaction between $\mathrm{Br}$ and $\mathrm{Si}$ atoms in silacyclopropylidene unit (Figure 1). However, the $\mathrm{Li}$ and $\mathrm{Br}$ atoms interact with $\mathrm{Si}$ atom in the silylenoidal $(\mathbf{S})$ and tetrahedral $(\mathbf{T})$ forms as it is seen from Figure 1. 
Characteristic bond lengths of these minima are listed in Tables 1-4. We could not find comparable experimental bond lengths in our calculated structures. Quantum chemical calculations shows that the shortest Lithium-Bromine bond is found to be in the $\mathbf{I}$ form rather than $\mathbf{S}$ or $\mathbf{T}$ forms in the range of 2.325-2.336 $\AA$ and the $\mathrm{Li}-\mathrm{Br}$ bond length of $\mathbf{I}$ forms is slightly larger than $\mathbf{G}$ forms. The calculations also indicate that, in the tetrahedral forms, the $\mathrm{Li}-\mathrm{Br}$ distances change greatly with regard to the reference bond lengths [18]. When the $\mathrm{Li}$ atom leaves from $\mathrm{Br}$ in the $\mathbf{T}$ form, the $\mathrm{LiSiBr}$ bond angles sharply elongates to $111.0^{\circ}, 112.3$ ${ }^{\circ}$, and $121.0^{\circ}$ in $-\mathrm{H},-\mathrm{CH}_{3}$, and $-\mathrm{SiH}_{3}$, respectively. The results also indicate that the $\mathrm{Si}-\mathrm{Li}$ bond of the $\mathbf{S}$ form decreases slightly compared to $\mathrm{H}_{3} \mathrm{Si}-\mathrm{Li}(2.479 \AA)$, whereas the most strongly elongated bond in the studied molecule $(\mathbf{S})$ is $\mathrm{Si}-\mathrm{Br}$ with a increasing value in the range from $0.303 \AA$ to $0.318 \AA$

In addition, we investigated the $\mathrm{LiBr}$ salt effect on bond lengths and angles of the free silacyclopropylidene moiety of the three complexes as compared to the bond length of $\mathrm{SiH}_{3}$ $\mathrm{CH}_{3}$ at the MP2/6-311+G(d,p) level of theory. Hence, we determined that the most elongation of the $\mathrm{Si}-\mathrm{C} 2$ bond occurs on the $\mathbf{I}$ form of $-\mathrm{SiH}_{3}$ with $0.093 \AA$ as compared to reference bond length of the $\mathrm{SiH}_{3}-\mathrm{CH}_{3}$ bond, $1.876 \AA$ [18]. On the other hand, the lowest elongation of the same bond is again on the $-\mathrm{SiH}_{3}$ substituted structure. Concerning the $\mathrm{Si}-\mathrm{C} 1$ distances in the $\mathbf{S}$ form of $-\mathrm{SiH}_{3}$, the elongations, as compared to the bond length of $\mathrm{SiH}_{3}-\mathrm{CH}_{3}(1.876 \AA$ ), is found to be $0.011 \AA$. Moreover, the calculated $\mathrm{C} 1 \mathrm{SiC} 2$ bond angles of the $\mathbf{S}$ and $\mathbf{T}$ forms of $\mathrm{C}_{2} \mathrm{H}_{4} \mathrm{SiLiBr}$ are higher than that of free silacyclopropylidene, $46.5^{\circ}$, whereas $\mathbf{I}$ forms have lowest ones.

From the energy results given in Tables $1-4$, the relative stability of the $\mathbf{S}, \mathbf{T}$, and $\mathbf{I}$ forms are clear at the MP2/6-311+G(d,p) level. The $\mathbf{S}$ forms are more stable than the $\mathbf{I}$ and $\mathbf{T}$ forms for all of them. We have also found that the $\mathbf{I}$ forms are energetically more stable than the $\mathbf{T}$ forms by $7.66 \mathrm{kcal} / \mathrm{mol}, 7.40 \mathrm{kcal} / \mathrm{mol}$, and $6.49 \mathrm{kcal} / \mathrm{mol}$ for $-\mathrm{H},-\mathrm{CH}_{3}$, and $-\mathrm{SiH}_{3}$ including zero-point energy at the MP2/6-311+G(d,p) level of theory, respectively.

Table 1. Selected bond lengths $(\AA)$, bond angles $\left(^{\circ}\right)$, and ZPVE-corrected energies (E, a.u.) for the Silylenoidal (S) and Inverted (I) forms of the $\mathrm{C}_{2} \mathrm{H}_{3} \mathrm{XSiLiBr}$ (where $\mathrm{X}=-\mathrm{H}$ ) at the MP2/6-311+G(d,p) level

\begin{tabular}{|l|c|c|c|}
\hline $\mathbf{X}=-\mathbf{H}$ & $\mathbf{S}$ & $\mathbf{I}$ & $\mathbf{T}$ \\
\hline $\mathrm{Si}-\mathrm{Li}$ & 2.446 & 3.021 & 2.437 \\
\hline $\mathrm{Si}-\mathrm{Br}$ & 2.547 & 2.569 & 2.316 \\
\hline $\mathrm{Li}-\mathrm{Br}$ & 2.337 & 2.327 & 3.918 \\
\hline
\end{tabular}




\begin{tabular}{|l|c|c|c|}
\hline $\mathrm{Si}-\mathrm{C} 1$ & 1.892 & 1.946 & 1.893 \\
\hline $\mathrm{Si}-\mathrm{C} 2$ & 1.892 & 1.947 & 1.893 \\
\hline $\mathrm{C} 1-\mathrm{C} 2$ & 1.529 & 1.539 & 1.531 \\
\hline $\mathrm{C} 2-\mathrm{X}$ & 1.088 & 1.087 & 1.088 \\
\hline $\mathrm{SiLiBr}$ & 64.2 & 55.6 & 33.5 \\
\hline $\mathrm{C} 1 \mathrm{SiC} 2$ & 47.6 & 46.5 & 47.7 \\
\hline $\mathrm{SiC} 2 \mathrm{X}$ & 117.9 & 119.0 & 118.9 \\
\hline$V$ & 76.45 & 151.33 & 78.72 \\
\hline $\mathrm{E}_{\text {rel }}$ & -2947.333433 & -2947.331979 & -2947.319771 \\
\hline
\end{tabular}

Table 2. Selected bond lengths $(\AA)$, bond angles $\left(^{\circ}\right)$, and ZPVE-corrected energies (E, a.u.) for the Silylenoidal (S) and Inverted (I) forms of the $\mathrm{C}_{2} \mathrm{H}_{3} \mathrm{XSiLiBr}$ (where $\mathrm{X}=-\mathrm{OH}$ ) at the MP2/6-311+G(d,p) level

\begin{tabular}{|l|c|c|c|}
\hline $\mathbf{X = - O H}$ & $\mathbf{S}$ & $\mathbf{I}$ & $\mathbf{T}$ \\
\hline $\mathrm{Si}-\mathrm{Li}$ & 2.452 & 3.072 & - \\
\hline $\mathrm{Si}-\mathrm{Br}$ & 2.532 & 2.534 & - \\
\hline $\mathrm{Li}-\mathrm{Br}$ & 2.343 & 2.336 & - \\
\hline $\mathrm{Si}-\mathrm{C} 1$ & 1.904 & 1.949 & - \\
\hline $\mathrm{Si}-\mathrm{C} 2$ & 1.896 & 1.961 & - \\
\hline $\mathrm{C} 1-\mathrm{C} 2$ & 1.521 & 1.519 & - \\
\hline $\mathrm{C} 2-\mathrm{X}$ & 1.419 & 1.417 & - \\
\hline $\mathrm{SiLiBr}$ & 63.7 & 54.0 & - \\
\hline $\mathrm{C} 1 \mathrm{SiC} 2$ & 47.2 & 45.7 & - \\
\hline $\mathrm{SiC} 2 \mathrm{X}$ & 116.0 & 122.6 & - \\
\hline$V$ & 64.91 & 91.48 & - \\
\hline $\mathrm{E}_{\text {rel }}$ & -3022.400007 & -3022.399002 & - \\
\hline
\end{tabular}

Table 3. Selected bond lengths $(\AA)$, bond angles $\left(^{\circ}\right)$, and ZPVE-corrected energies (E, a.u.) for the Silylenoidal (S), Inverted (I), and Tetrahedral (T) forms of the $\mathrm{C}_{2} \mathrm{H}_{3} \mathrm{XSiLiBr}$ (where $\left.\mathrm{X}=-\mathrm{CH}_{3}\right)$ at the MP2/6-311+G(d,p) level

\begin{tabular}{|l|c|c|c|}
\hline $\mathbf{X}=-\mathbf{C H}_{\mathbf{3}}$ & $\mathbf{S}$ & $\mathbf{I}$ & $\mathbf{T}$ \\
\hline $\mathrm{Si}-\mathrm{Li}$ & 2.447 & 3.022 & 2.438 \\
\hline $\mathrm{Si}-\mathrm{Br}$ & 2.541 & 2.561 & 2.315 \\
\hline $\mathrm{Li}-\mathrm{Br}$ & 2.340 & 2.326 & 3.950 \\
\hline $\mathrm{Si}-\mathrm{C} 1$ & 1.898 & 1.958 & 1.901 \\
\hline $\mathrm{Si}-\mathrm{C} 2$ & 1.899 & 1.947 & 1.898 \\
\hline $\mathrm{C} 1-\mathrm{C} 2$ & 1.525 & 1.534 & 1.526 \\
\hline $\mathrm{C} 2-\mathrm{X}$ & 1.518 & 1.520 & 1.516 \\
\hline SiLiBr & 64.0 & 55.4 & 32.8 \\
\hline $\mathrm{C} 1 \mathrm{SiC} 2$ & 47.3 & 46.2 & 47.3 \\
\hline
\end{tabular}




\begin{tabular}{|l|c|c|c|}
\hline SiC2X & 120.4 & 119.1 & 121.5 \\
\hline$V$ & 66.74 & 107.55 & 75.83 \\
\hline $\mathrm{E}_{\text {rel }}$ & -2986.502474 & -2986.501245 & -2986.489437 \\
\hline
\end{tabular}

Table 4. Selected bond lengths $(\AA)$, bond angles $\left(^{\circ}\right)$, and ZPVE-corrected energies (E, a.u.) for the Silylenoidal (S), Inverted (I), and Tetrahedral (T) forms of the $\mathrm{C}_{2} \mathrm{H}_{3} \mathrm{XSiLiBr}$ (where $\left.\mathrm{X}=-\mathrm{SiH}_{3}\right)$ at the MP2/6-311+G(d,p) level

\begin{tabular}{|l|c|c|c|}
\hline $\mathbf{X}=-\mathrm{SiH}_{\mathbf{3}}$ & $\mathbf{S}$ & $\mathbf{I}$ & $\mathbf{T}$ \\
\hline $\mathrm{Si}-\mathrm{Li}$ & 2.453 & 3.007 & 2.442 \\
\hline $\mathrm{Si}-\mathrm{Br}$ & 2.546 & 2.569 & 2.300 \\
\hline $\mathrm{Li}-\mathrm{Br}$ & 2.340 & 2.325 & 4.128 \\
\hline $\mathrm{Si}-\mathrm{C} 1$ & 1.887 & 1.942 & 1.891 \\
\hline $\mathrm{Si}-\mathrm{C} 2$ & 1.901 & 1.969 & 1.912 \\
\hline $\mathrm{C} 1-\mathrm{C} 2$ & 1.538 & 1.541 & 1.536 \\
\hline $\mathrm{C} 2-\mathrm{X}$ & 1.853 & 1.859 & 1.844 \\
\hline $\mathrm{SiLiBr}$ & 64.1 & 55.8 & 28.5 \\
\hline $\mathrm{C} 1 \mathrm{SiC} 2$ & 47.9 & 46.4 & 47.6 \\
\hline $\mathrm{SiC} 2 \mathrm{X}$ & 119.1 & 118.2 & 117.2 \\
\hline$V$ & 66.37 & 84.34 & 30.30 \\
\hline $\mathrm{E}_{\text {rel }}$ & -3237.530471 & -3237.529050 & -3237.518699 \\
\hline
\end{tabular}

\section{Conclusion}

In the present study, we have carried out a high level ab initio study of the $\mathrm{C}_{2} \mathrm{H}_{3} \mathrm{XSiLiBr}$ (where $\mathrm{X}=-\mathrm{H},-\mathrm{CH}_{3},-\mathrm{SiH}_{3}$, and $-\mathrm{OH}$ ) types of molecules. $\mathrm{C}_{2} \mathrm{H}_{3} \mathrm{XSiLiBrs}$ has three stationary structures: silacyclopropylidenoid (S), tetrahedral (T), and inverted (I), which were obtained at the MP2/6-311+G(d,p) level of theory. The theoretical results indicate that the $\mathbf{S}$ forms are energetically the most stable ones in the gas phase. Our calculations also depict that the $\mathbf{T}$ form of $-\mathrm{OH}$ coul not be optimized, whereas the others are found to be minima with no imaginary frequencies at the MP2/6-311+G(d,p) computational level.

\section{Acknowledgments}

This study was supported financially by the Scientific and Technological Research Council of Turkey (Grant No. TUBITAK TBAG 212T049).

\section{References}


[1] H. Gilman, D. Peterson J. Am. Chem. Soc. 87 (1965) 2389.

[2] O. Nefedow, M. Manakow Angew. Chem. 76 (1964) 270.

[3] T. Clark, P. Schleyer, J. Organomet. Chem. 191 (1980) 347.

[4] S. Feng, G. Ju, C. Deng, Sci. China B 9 (1991) 907.

[5] S. Feng, G. Ju, C. Deng, Sci. China B 35 (1992) 523.

[6] S. Feng, D. Feng, C. Deng, Chem. Phys. Lett. 214 (1993) 97.

[7] D. Feng, S. Feng, C. Deng, Chem. J. Chin. Univ. 17 (1996) 1108.

[8] D. Feng, S. Feng, C. Deng, Chin. J. Chem. 13 (1995) 481.

[9] D. Feng, S. Feng, C. Deng, Chem. J. Chin. Univ. 19 (1998) 451.

[10] S. Feng, C. Deng, Acta Chim. Sin. 51 (1993) 138.

[11] W. Li, B. Gong, J. Cheng, C. Xiao, Acta Chim. Sin. 65 (2007) 1573.

[12] A. Azizoglu, C.B. Yildiz Organometallics 29 (2010) 6739.

[13] A. Azizoglu, C.B. Yildiz J. Organomet. Chem. 715 (2012) 19.

[14] C.B. Yildiz, A. Azizoglu Struct. Chem. 33 (2012) 1777.

[15] A. Azizoglu, R. Ozen, T. Hokelek, M. Balci J. Org. Chem. 69 (2004) 1202.

[16] M. Christl, M. Brauen, H. Fischer, S. Groetsch, G. Müler, D. Leusser, S. Deurlein, D. Stalke, M. Arnone, B. Engels Eur. J. Org. Chem. 2006 (2006) 5045.

[17] B. Kilbas, A. Azizoglu, M. Balci J. Org. Chem. 74 (2009) 7075-7083.

[18] Reference bond lengths calculated at the MP2/6-311+G(d,p) level of theory: $\mathrm{H}_{3} \mathrm{Si}$ $\mathrm{Br}=2.229 \AA, \mathrm{H}_{3} \mathrm{Si}-\mathrm{CH} 3=1.876 \AA, \mathrm{H}_{3} \mathrm{Si}-\mathrm{Li}=2.479 \AA$, and $\mathrm{Li}-\mathrm{Br}=2.187 \AA$.

[19] W.J. Hehre, L. Radom, P.v.R Schleyer, J.A. Pople (1986) ab initio molecular orbital theory. Wiley, New York

[20] M. J. Frisch and G. W. Trucks and H. B. Schlegel and G. E. Scuseria and M. A. Robb and J. R. Cheeseman and Montgomery, Jr., J. A. and T. Vreven and K. N. Kudin and J. C. Burant and J. M. Millam and S. S. Iyengar and J. Tomasi and V. Barone and B. Mennucci and M. Cossi and G. Scalmani and N. Rega and G. A. Petersson and H. Nakatsuji and M. Hada and M. Ehara and K. Toyota and R. Fukuda and J. Hasegawa and M. Ishida and T. Nakajima and Y. Honda and O. Kitao and H. Nakai and M. Klene and X. Li and J. E. Knox and H. P. Hratchian and J. B. Cross and V. Bakken and C. Adamo and J. Jaramillo and R. Gomperts and R. E. Stratmann and O. Yazyev and A. J. Austin and R. Cammi and C. Pomelli and J. W. Ochterski and P. Y. Ayala and K. Morokuma and G. A. Voth and P. Salvador and J. J. Dannenberg and V. G. Zakrzewski and S. Dapprich and A. D. Daniels and M. C. Strain and O. Farkas and D. K. Malick and A. D. Rabuck and K. Raghavachari and 
J. B. Foresman and J. V. Ortiz and Q. Cui and A. G. Baboul and S. Clifford and J. Cioslowski and B. B. Stefanov and G. Liu and A. Liashenko and P. Piskorz and I. Komaromi and R. L. Martin and D. J. Fox and T. Keith and M. A. Al-Laham and C. Y. Peng and A. Nanayakkara and M. Challacombe and P. M. W. Gill and B. Johnson and W. Chen and M. W. Wong and C. Gonzalez and J. A. Pople (2003) Gaussian 03. Revision C02. Gaussian, Inc., Pittsburgh

[21] R. Dennington, T. Keith, J. Millam, K. Eppinnett, W.L. Hovell, R. Gilliland (2003) GaussView, Version 3.09, Semichem, Inc., Shawnee Mission 